\title{
The salience of liminal spaces of learning: assembling affects, bodies and objects at the museum
}

\author{
Dianne Mulcahy \\ Melbourne Graduate School of Education, University of Melbourne, Melbourne, VIC 3010, Australia \\ Correspondence to: Dianne Mulcahy (monicadm@unimelb.edu.au)
}

Received: 1 June 2016 - Revised: 14 December 2016 - Accepted: 6 February 2017 - Published: 7 March 2017

\begin{abstract}
In this article, I work toward producing understandings of learning as liminal and as located in a liminal space. Framed as learning through the in-between, I engage with the concept of liminality as a way of unravelling the complexity of the practice of learning at the museum. Deploying data from video-based case studies of 40 school students' engagements with learning over the course of a visit to Museum Victoria, Australia, and utilising an analytic of assemblage, I map the spatial dynamics of learning in action. From analyses undertaken, it is argued that liminal spaces of learning open up in museum education and have a special salience. They have the potential to "jump start" the learner out of a comfortable state of mind and into a state of productive uncertainty. They also serve as a location for potential critique. More broadly, these analyses direct attention to the centrality of material practice and agency to liminality and liminal learning.
\end{abstract}

\section{Introduction}

In asking the questions what else could children's geographies do? and what more could be done with children's geographies, Horton and Kraftl (2006) challenge researchers to open up new ways of thinking about how children learn, think and know, and the places in which they do this. In this article, I take up this challenge by investigating the learning of children and young people within museums. Following Kraftl (2013), Bauer (2015, p. 620, emphasis added) argues that "it is precisely the spaces in-between, the in/formal boundary zones that are the most illuminating fields to study". These spaces afford "a more flexible understanding of the spatialities, rationalities and materialities of learning" (Bauer, 2015). Additionally, I add its affectivities. Affects "begin in the interstitial space between agents" (Kraftl, 2013 , p. 50, original emphasis). In this article, I take spaces in-between to be liminal ones and advance an articulation of them as sociomaterial assemblages or webs of relations between people, spaces and things. Thus, in the context of school children visiting the museum, they potentially enter into a relationship with museum educators, exhibition spaces and exhibits such that it is difficult to determine who and/or what prompts their learning and where exactly it lies. "What is between is where the real action is" (Cooper and Law, 1995 , p. 245, original emphasis).

As Thomassen (2015, p. 40) describes it, "liminality refers to something very simple and universal: the experience of finding oneself at a boundary or in an in-between position, either spatially or temporally". Museums lend themselves to investigating experiences of liminality inasmuch as their collections often involve "the exotic, the strange - museums as houses of mystery" (Witcomb, 2003, p. 24), potentially giving rise to experiences of a transformational kind. Museums are also increasingly taking on what is characterised as "difficult subject matter" evident in a proliferation of exhibitions related to conflict, violence, loss and death (Bonnell and Simon, 2007). Out-of-ordinary experiences are on offer that invite boundary work: negotiating in-between situations and conditions such as the uncertainty of war (a theme commonly "curated" within museums) or of climate change (as discussed in Sect. 5.1 below). Providing the possibility of liminal learning, these experiences need to be managed. Thus a museum educator who participated in the empirical research reported the following comments:

When you go to a museum and something slows you down, that often improves or deepens the experience of learning as a visitor ... And so hope- 
fully, although it might seem a bit stagey at first, including to students, they might go - "how long are we going to spend in this room?" - what's happening as they are kind of coerced into looking more closely at exhibits, will actually allow them to think well.

Here, it can be argued, museum educators act as "masters of ceremony", guiding the characteristically unstructured, or partially structured, learning experience that museum education involves, as, I propose, spatial arrangements of rooms also do. I credit the idea that human agency and material agency can both contribute to a liminal learning experience. Drawing a distinction between anthropological liminality (which concerns specifically human interactions) and ontological liminality, Stenner and Moreno-Gabriel (2013, p. 244) forward the Whiteheadian philosophic idea that the world is not "fundamentally bifurcated into 'social' and 'natural' portions corresponding to 'subject' and 'object"'. "All reality is ultimately composed, not of brute matter, but of events or occasions" (Stenner and Moreno-Gabriel, 2013, original emphasis). I, too, take this view. The contribution of this article lies in questioning the limitations that a humanist framework places on our understanding of learning and, particularly, museum learning, in which the materiality of collections plays a large part (Hooper-Greenhill, 2007, p. 170). Concomitantly, the centrality of material practice and material agency to liminality and liminal learning is claimed.

The structure of the article is as follows. Initially, I provide an account of liminality and argue that it can be seen as a generative trope for understanding learning and, most particularly, museum learning. Next, I consider the notion of liminal space, viewed through the lens of space as assemblage: space as composed of heterogeneous entities (e.g. discursive, material) and best understood as spatiality - space as "constantly in the process of being made" (Massey, 1999, p. 265). Then, deploying data from video-based case studies of 40 school students' engagements with learning over the course of a visit to Museum Victoria, Australia's largest public museum, and utilising an analytic of assemblage (Deleuze and Guattari, 1983, 1987; Latour, 2005), I map the spatial dynamics of learning in action using two exhibition spaces as the empirical ground. Altogether, it is argued that liminal spaces of learning open up in museum education and have a special salience. They have the potential to "jump start" the learner out of a comfortable state of mind and into a state of productive uncertainty. They can also be highly ethically and politically charged such that the learner becomes "other" in relation to others, providing the possibility of significant social change.

\section{On liminality: temporal and spatial relations}

In what follows, I outline two academic discourses of liminality that tend to be taken up in the educational literature.
While these discourses intersect, what they presuppose and imply for educational practice is radically different. Additionally, while each rendering of liminality can contribute significantly to better understanding this practice, the "spatial" rather than "temporal" version of the liminal is particularly powerful. It is a location of potential critique (Mansaray, 2006, p. 175).

\subsection{Liminality as transitional time}

Conventionally, the word "liminal" derives from the Latin word limen, meaning literally "threshold", of, relating to or being in an intermediate state or condition. "'Of or pertaining to a threshold', the liminal already in some way connotes the spatial: a boundary, border, a transitional landscape", such as the beach (Andrews and Roberts, 2012, p. 1. original emphasis). The concept of liminality was introduced in anthropology by Arnold van Gennep in 1909 and eventually taken up and developed further by Victor Turner as any "betwixt and between" situation or object (Turner, 1967). The liminal is also the "initial stage of a process': it therefore exhibits temporal qualities, marking a beginning as well as an end, but also duration in the unfolding of a spatio-temporal process" (Andrews and Roberts, 2012, p. 1, original emphasis). In the learning and education literatures, it is the temporal version of liminality that tends to prevail. Thus, applications of the concept of liminality have emphasised those periods where people or groups transit from one recognised psychosocial state to another. For example, in social work field education, "the student experiences a change in status to 'student social worker' who is neither fully student nor social worker but 'betwixt and between"' (Parker et al., 2012, p. 149). Similarly, in teacher education, student teachers experience a change in status to "teacher candidates" who are neither fully students nor teachers. Children and young people too are commonly characterised as being in transition, or suspended in transitional time, before they achieve the state of adulthood. However, like social work students and student teachers, they are not conceived as constantly in the process of being made: this version of liminality presupposes a transition to an end state. Commonly, childhood is thought to be about growing up. The end state is both privileged and already given. In this transitional conception of liminality, singular and discrete conditions and states (childhood, youth, adulthood; teacher candidate, teacher) are valorised and assimilability to certain of these is supported. While strengths attach to this conception, limitations also present. Thus,

the liminal is viewed from the perspective of the dominant social order, which is static, and the dynamic energy of the liminal is harnessed towards integration, which is why the liminal is a "transitional" state or process. ... In essence the liminal is a teleological concept, stemming from certain functionalist perspectives on society. That is, the 
liminal is concerned with assimilation and social order (Mansaray, 2006, p. 174).

A transitional conception of liminality can be considered to make for a restrictive geography of learning and education. In privileging a given end state, effecting social change is a challenge.

\subsection{Liminality as indeterminate space}

The second deployment of the concept of liminality presupposes a less unidirectional and more processual understanding. Here, the term liminal refers to "occupying a position at, or on both sides of, a boundary" (http: //www.oxforddictionaries.com/definition/english/liminal). It is framed as more a matter of space (boundary) than time (initial stage of a process) and as ontologically indeterminate. As Cooper (Chia and Kallinikos, 1998, p. 148, original emphasis) notes, "boundary is an intrinsically ambiguous concept. For the boundary both separates and joins. As such, it represents a dilemma or an irreducible difference that cannot be decisively solved". In this rendering of liminality, no prespecification of an end state is in view. Liminality is less a state that is occupied than a practice that is enacted or performed, for example becoming a liminal learner at the museum. As Mansaray (2006, p. 175, original emphasis) explains:

... the liminal ... is an open form of internal differentiation and refers to relations in which the final condition is not pre-set, but rather is potentially negotiable and contestable. Liminality is the as yet unnamed space within a practice, a group or an organisation, a feature of its development, which rather than being telos can go any number of ways. Liminal entities are unclassifiable because they occupy a space of becoming, a transgressive "boundary position", and are unfinished, unstable and destabilising.

In a Deleuzian rendering of liminal space, this space is rhizomatic (Deleuze and Guattari, 1983). Characterised by openness, indeterminacy and movement, this rendering invites a reimagined geography of learning and education. For some commentators on liminality in the social sciences and humanities, the spatial perspective is central. "Having essentially to do with an in-between position, the point of departure for any analysis of liminality must be spatial" (Thomassen, 2014, p. 11, original emphasis). Singular categories such as child, adolescent and adult are multiplied and, as such, complexified: the internally differentiated category of teen-adult comes into view. Spaces that get outside the dualisms (child-adult) involve complex connections between disparate knowledge and practices as well as mutation and movement, as the empirical material seeks to show. Underscored by the concept of spatiality, whereby space and society are taken to be inextricably linked (Kraftl, 2016, p. 153), a spatial perspective on liminality and learning affords the idea that the learner and the space itself can be an active agent of change. Going beyond the human-centred focus of the "temporal" version of liminality, this perspective provides the possibility of making us more attentive to the role of non-human aspects of the liminal learning encounter (e.g. material objects, architecture, natural forces) and their contribution to the geography of learning and education. These aspects are of particular significance in museum learning and education. While acknowledging that "the qualities of liminality pertain to human experiences" (Thomassen, 2014, p. 4), in what follows I highlight its material dimensions towards exploring what a "more than human" (Whatmore, 2006) account of liminality offers.

\section{Thinking liminality and learning in an assemblage frame}

Two expansive metaphors of learning in space-time (Massey, 1999) concern learning assemblages and learning networks. As Müller (2015, p. 27) expresses it, assemblage thinking (Deleuze and Guattari, 1983, 1987) and actor-network theory (Latour, 2005; Law, 2009) have been at the forefront of the revalorisation of the material, or commonly, the sociomaterial: "the co-constitution between humans and nonhumans". Increasing attention is being given in education to the materiality of learning and to sociomaterial assemblages (Fenwick and Landri, 2012; Introna, 2013; Sorensen, 2009) whereby "entanglements" of the social and the material (e.g. discourses, bodies, objects, architectures, climates) can be traced. Potentially, both assemblage thinking and actor-network theory have much to offer with regard to a more than human perspective on liminality. Each challenges the anthropocentric impulses attaching to the original anthropological use of the term ${ }^{1}$ and takes us into the territory of ontological liminality (Stenner and Moreno-Gabriel, 2013) which is guided by the Whiteheadian principle "that how an actual entity (such as a liminal space) becomes constitutes what that actual entity is" (Whitehead, 1978, p. 23, original emphasis).

In a Deleuzian framing, a liminal space has no beginning or end. It is emergent, a temporal and spatial configuration or assemblage that "allows us to name a terrain" (Fendler, 2013, p. 787). Based on interdependencies between subject and object, person and world, "assemblage has been increasingly used to designate, not an arrangement or a state of affairs, but an ongoing process of arranging, organising or congealing how heterogeneous bodies, things or concepts come 'in

\footnotetext{
${ }^{1}$ The foundational anthropological work of van Gennep for example, attends to rituals marking individual or collective passages through the life cycle (Szakolczai, 2009, p. 141). Materiality is extensively referenced in this work, yet I would not call it materialist in the sense of "more than human" where humans and non-humans are deemed to be co-constituting.
} 
connection with' one another" (Kennedy et al., 2013, p. 45, original emphasis). In simple terms, an assemblage is "a way of explaining configurations of power relations and arrangements" (Ringrose and Rawlings, 2015, p. 93), the analytic point being to unpick the components of the assemblage and ascertain how they work together for a certain time to create an identity (liminal learner), claim a territory (liminal space, liminal learning) and enact a politics (who or what is privileged in the process of assembling and who or what is marginalised).

Thinking in an assemblage frame affords considering liminality and learning as "events, actions and encounters between bodies, rather than simply entities and attributes of subjects" (Puar, 2012, p. 58). The relational ontology that underscores assemblage thinking and actor-network theory takes the assumptive position that the world is not divided into a human domain of subjects and culture and a nonhuman domain of objects and nature. Much as Whiteheadian process philosophy has the potential to do, these onto-methodologies (Nimmo, 2016) can contribute fresh understandings of liminality and liminal learning. Emphasis is placed on the possibility of material practices playing as significant a part in liminality as human practices.

\section{Data and methods}

The project reported here was a small-scale, 1-year study (2013-2014) sponsored by the author's university in collaboration with Museum Victoria. Data were collected at each of this museum's three venues, Melbourne Museum, the Immigration Museum and Scienceworks (see http:// museumvictoria.com.au/). Video-based case studies of "naturally" occurring interactions of school visitors in selected exhibition spaces at these museums were conducted. Altogether, 40 students took part in the filming, ranging in age from 8 to 16 with the filming at each museum being of approximately one hour's duration. A number of children filmed were wearing GoPro cameras to "capture" what they saw and said individually over the course of the filming. Wearable cameras afford exploration of the "inherent spatialities of the liminal" (Andrews and Roberts, 2012, p. 2) and learning "on the fly". The rich imbrication of liminality, learning and spatiality can be "captured" as it occurs. The video-based case studies were accompanied by interviews undertaken with lead curators on the exhibitions (three altogether), museum educators and participating teachers (six altogether) and participating students (six altogether). The participating schools spanned different schooling sectors, that is, a Catholic primary school, an independent (non-government) girls' secondary school and a government secondary college.

In what follows, a selection from the data collected at Scienceworks, a natural sciences museum, and from the Immigration Museum, a museum primarily displaying Australia's immigration history, only is worked. As described more fully below, the exhibitions in which the school visitors were filmed at each of these museums, respectively, were Think Ahead and Identity: Yours, Mine, Ours. Placing the visitor in a boundary position both spatially and temporally, these exhibitions and their specific exhibits were deemed to furnish the conditions necessary for a study of liminal spaces of learning. In line with the onto-methodologies outlined above, the sociomaterial practices that give rise to liminality and liminal learning (or not) in these exhibition spaces served as the analytic focus. Thus, how affects, bodies and objects came in connection with one another was traced (Fenwick et al., 2011). The analytic work on the data collected concerned less a question of signification - what does appropriating a liminal space mean for learning? - than a question of capacity - what a liminal space does, what transformations and transitions are brought into effect through liminal space and the practice of liminal learning? In other words, how do liminal spaces form and what work do they do?

\section{Assembling liminal spaces of learning}

\subsection{Assemblage as future-present: Super Future You}

Developed for a new permanent exhibition at Scienceworks called Think Ahead, Super Future You is a full-body interactive that, in the developer's terms, "allows visitors to add 3D models of hypothetical body augmentations to a real-time video stream of themselves" (see http://www.lightwell.com. $\mathrm{au} /$ super-future-you/). Initially, visitors walk into a "podlike" station and see a 1:1 scale representation of themselves on a large screen. They are then scanned and can choose from over 25 body enhancements (for example, wings, a robotic trunk, rocket boots, a pollution filtering re-breather, cybernetic brain implants) to create a "super future" version of themselves. Once they have tested out their augmented selves and played a quick game, an animated GIF of their experience is captured for them to send on to their inboxes at home or school or to upload to their social media sites. Entering the "pod-like" station that is Super Future You can be likened to entering a liminal landscape which, as Ward (2012, p. 186) comments, involves opening up a space of free play and opening up oneself to experiences beyond the boundaries normally set by society. Albeit a space of free play, Super Future You also demands tests of the visitor towards establishing how well she does in this out-of-ordinary situation.

Science museums have been described as a "lively chaos ... filled with children running about, pushing buttons, walking through apparatus that makes them feel different" (Kolb, 2013, pp. 43-44). This description aptly captures the dynamics of a visit by a year 7 school group ${ }^{2}$ from a government secondary college to Scienceworks and the affective experiences had within its exhibition spaces. As noted in the introduction to the article, affects "begin in the interstitial space

\footnotetext{
${ }^{2}$ In Australia, the average age of a year 7 child is 12 .
} 

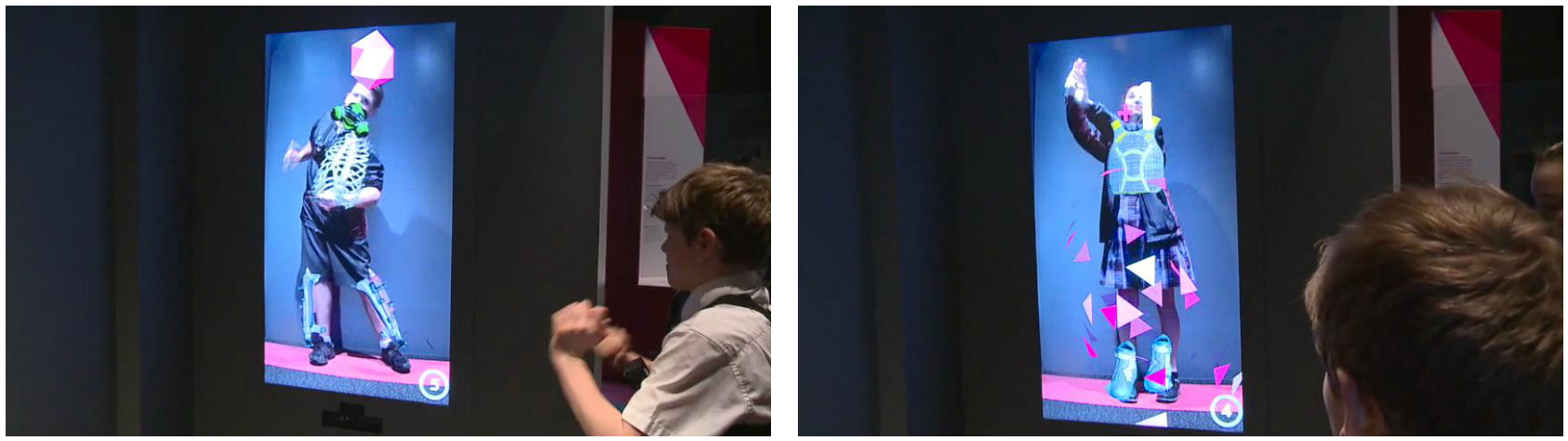

Figure 1. Year 7 students trying out their "new" bodies and testing how they work with another student looking on and imitating the actions.

between agents" (Kraftl, 2013, p. 50, original emphasis). In association with the lively atmosphere that a science museum presents, affects have the capacity to make children "feel different", or, in a more sociomaterialist frame, make their bodies move "from one power of existence to another" (Massumi and McKim, 2009, p. 2). An affect is a "felt moment of bodily moving on" (Massumi and McKim, 2009, p. 3) from which a new or renewed sense of self can emerge. Something of this "bodily moving on" and its affects can be seen in the following Figure in which visiting students are shown interacting with Super Future You.

The curator of Think Ahead describes the interactive shown in Fig. 1 in these terms:

Super Future You or Super Future Me is one which is looking at the idea of how body implants or replacement parts are becoming increasingly part of just remaining healthy as we age, or remaining healthy as we have ... you know, depending on what happens to us, that we might need to have a replacement hip or a replacement heart valve, but increasingly these devices and implants might actually enhance what we're able to do. And so in this experience, visitors can select a number of things to try on their own bodies. Some are quite fantastic like wings or a trunk, but others are more fully embedded in real technology which is being developed at the moment such as the bionic eye or bionic ear. And once you've selected something for your head, something for your torso, and something for your legs, you then get the opportunity to try out your new body - you see yourself moving as you play a game to try and catch targets, and you test out how your new body works.

Super Future You offers visitors an affective and a liminal learning experience. While crediting the idea that affect can literally be liminal (Stenner and Moreno-Gabriel, 2013, p. 238), I will take each of these categories separately and in turn. First, the practice of enhancing bodily capacity is a fun activity - "we're influenced by ideas about game-like learn- ing" (curator) - that provides opportunities to experience learning as fun. When asked in an interview about the benefit of museum visits with regard to learning, one of the two year 7 students commented that "personally, I think it's more fun than learning" and added the qualifier, "the fun helps learning". Throughout this interview, emphasis was placed by the students on the value of hands-on activities and interacting with materials: "Well (the) museum is all hands-on, like none of it you're listening to (teachers) and you're just writing stuff down. It's all hands-on, and I really like that". As Lorimer (2013, p. 64) comments, the sensory and affective register of touch (the haptic) can bring together bodily practice (I touch) and emotional energies (I am touched). This comment was well supported in an interview: "I've certainly seen, you know, where really those whole body immersive experiences can really have an amazing and affective learning outcome" (science museum educator).

Super Future You also offers the experience of humantechnology interactions. Or, broadly, interactions between human meaning-making and materiality such as the design of the exhibition space with its "futuristic feel" and the design of the pod-like station as a full-body interactive. As Barad (2007) puts it, these interactions are best conceived as the entanglement of matter and meaning. Using current and future advances in science and technology to create a super future self, it invites visitors to think about and physically experience the future. ${ }^{3}$ As the science museum educator comments: "Think Ahead, as the name indicates, is about thinking into the future, and so the space is designed, you know, to feel like you're walking into the future. The archways as they walk in have that futuristic feel. The ... vacuum tubes that sort of go around were inspired by Futurama the cartoon, the animation. So again to give it that future feeling". The pod into which visitors walk is a physical space between presentday and future bodily reality that may (or may not) morph into a liminal space, providing the possibility of becoming "super sustainable future you", or "super robust future you" or "super tech future you" (Tender, 2012, p. 1: Interactive

\footnotetext{
${ }^{3}$ Or, better perhaps, a curatorial vision of the future.
} 
and Multimedia template, Scienceworks Think Ahead Exhibition, 2012, p. 1). The super future self can assume different forms, opening the way for the visitor to become something other than her present-day self or perhaps a "hybrid" of the two. One of the year 7 students in an interview reported that "you got to choose what you wanted and it would generate for you".

An entanglement of human subject and 3-D object, learning with Super Future You is a liminal learning experience through which materiality and meaning come into connection with one another. "Super Future You, you know, again it's a game, they're in it, it's visceral, they're just ... they're moving their whole body as part of it, but it starts to raise that awareness about the actual, you know, what the exhibit's actually talking about, which is prosthetics" (science museum educator). As Ellsworth (2005, p. 16, original emphasis) puts it, "the look of the learning self ... gives form to the sensation of simultaneously being with oneself and being in relation to things, people, or ideas outside oneself". She elaborates: "It is the look of someone who is in the process of losing something of who she thought she was" (Ellsworth, 2005 , p. 16) and, perhaps, of gaining something of who she thought she was not. This look can be called a look of liminality. It was discernible on the faces of those participating in the Super Future You experience and in other project video data.

Some sense of the liminal quality of the learning on offer through the visit to Scienceworks can be grasped in the visiting science teacher's report on the value of museum visiting:

(T)here needs to be a link between what they're experiencing at the museum or at Scienceworks or in that space, to them being able to bring that back to school and continue that discussion, and have them kind of move up to that next level where it's not us feeding them the information, but them starting to think about - well, what if we didn't have an atmosphere? What if there was no water on a planet? How is that going to affect being able to live on it? So I think for them being able to enter a space and see things that we hadn't seen at school or investigated at school ... I'm a big believer [in] museum education and ... giving the students an opportunity to learn in a different way. ... What I would love for them to be able to see is that science isn't just about what we learn at school in the classroom, that there is a connection to everyday, and hopefully in the future.

Museum education offers the experience of "what if" learning: learning about the present planet and what is required to sustain it and its inhabitants into the future. Here, this learning assembles diverse elements (atmosphere, water, humans, inhabitation, museum, school) in productive relations of what I call "assemblage as future-present". I write future-present with an en dash to indicate the interdepen- dence of the two temporalities and reflect their entangled relationship. Thus, these temporalities are not linear and sequential as the transitional conception of liminality has it. They assemble or come into being together. Super Future You implies the idea of the mutual imbrication of present and future, with no guarantee of a future being able to be given: "what if we didn't have an atmosphere? What if there was no water?" It is a liminal space par excellence - the "final condition is not pre-set" (Mansaray, 2006, p. 175) - with the power to prompt critical and ethical thinking and have students see "that science isn't just about what we learn at school in the classroom, that there is a connection to everyday, and hopefully in the future".

\subsection{Assemblage as identity/difference: Welcome Hallway}

Opening at the Immigration Museum in 2011, Identity: Yours, mine, ours is "an exhibition that takes a mirror to our culturally diverse society and asks what it means to belong or not belong - in Australia today" (Identity \& belonging: A guide for students, p. 3). It addresses issues around diversity, difference, prejudice and racism as well as the many ways in which identities are enacted. At the entry point to the exhibition is an immersive video installation, Welcome Hallway, ${ }^{4}$ that seeks to unsettle the identities of visitors to it. As the exhibition's curator relates:

We knew we wanted an experience that people entered that was fairly transitional, that would help sort of take them out of where they'd been before and enrol them in something that was going to be quite a different exhibition experience and an emotional experience.... In Welcome, we wanted to suggest that diversity was there. So in that, there are clearly people of different socioeconomic backgrounds; there's obviously gender; there's age, a lot of age differential; there's, you know, Collingwood fans; ${ }^{5}$ there's people of different ethnic backgrounds, obviously; faith backgrounds; elite schoolchildren. ... We wanted visitors to enter that space and ... to challenge their assumptions about who they might assume would accept them or reject them or welcome them or not welcome them.... You might be a Muslim woman who's rejected by the other hijab-wearing Muslim women. ... Or you might be ... there's a group of three young men whose welcome is incredibly

\footnotetext{
${ }^{4}$ For an account of this installation provided by its creator, see http://museumvictoria.com.au/immigrationmuseum/ discoverycentre/identity/welcome-lynette-wallworth/

${ }^{5}$ The term "Collingwood fans" refers to supporters of an Australian Football League team called Collingwood. Collingwood supporters have a reputation for being working class which, in Australia, can mean "bogan" and feral.
} 
warm ... which might surprise you, but their rejection is quite menacing. ... It's about who you belong with or don't belong with or think you might belong (with) or challenge yourself about who you might feel you belong with.

The space of the Welcome Hallway is a space of welcomes extended and withdrawn in unexpected ways that test the limits of one's sense of belonging and sense of self and others: "In working the space between the visitor and the display, such exhibitions ... work poetically to provoke unsettlement in their viewers by playing with their collective memories about the past, challenging them to rethink who they think they are and who they think they are viewing" (Witcomb, 2013, p. 256). In the terms of the earlier discussion on liminality, it can be conceived as an indeterminate boundary space. The welcome extended and withdrawn by particular social groups is a liminal entity; ontologically indeterminate, it both includes and excludes.

Thus, for a small group of visitors from an independent girls' secondary school, two women from Oxfam ${ }^{6}$ in fair trade T-shirts and with arms folded unwelcomingly (see Fig. 2) provoke the following exchange:

- S.1: I'm getting a bit of the stabbing vibe from a lot of people. (Oxfam women present in Welcome Hallway)

- S.2: How can you be judgemental, you're Oxfam?

- S.3: Oxfam people would not be like that.

- S.2: Like what did we do to them?

- S.3: I just made a stereotypical judgement. I just said Oxfam people.

- S.2: (reading slogan on T-shirt) Make trade fair

- S.3: By glaring at each other?

Clearly, this student group identifies with Oxfam and "Oxfam people", with members of it being surprised and affectively unsettled by the identities embodied in the encounter: "Oxfam people would not be like that". In the interview, two of the students, Rihanna and Nicky, provided an extended account of their experience in the Welcome Hallway:

Well ... it was easy to make stereotypical kind of judgements based on the way they were acting, but I could actually feel it in my head, like you see a man with ... like a man and a woman and they're all kind of in footy gear and stuff, and they're all like this and you're thinking, you know, "oh yeah you're angry because I'm barracking for a different team" or "your favourite team just lost", or "you're just that sort of person", but then you see

\footnotetext{
${ }^{6}$ Oxfam is an international, not-for-profit, community-based aid and development organisation.
}

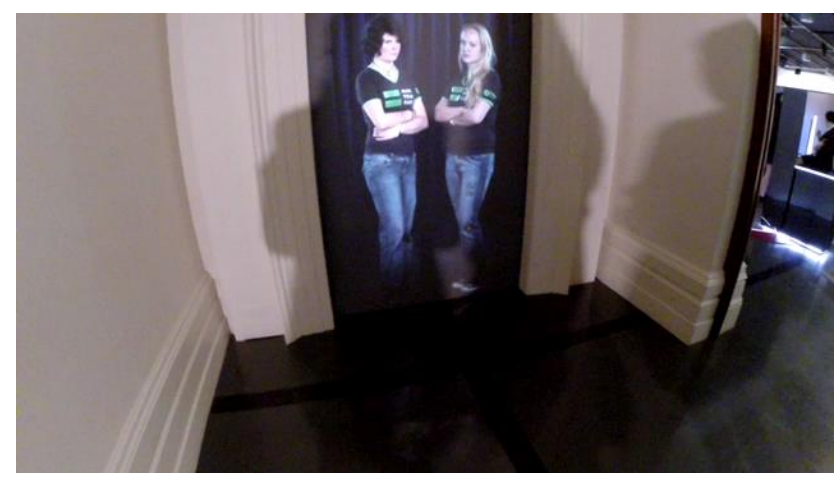

Figure 2. Four year 10 students encountering Oxfam women in the Welcome Hallway.

them waving, and you're like - "oh yeah, it's game day, you're really excited". And you can make the two stereotypes immediately, and you have them already in your head, and it's kind of amazing to see the same two people do two different things, and you stereotype them completely differently. ... It unsettled me that I could make those judgements and see them as different people. Like the difference between the people - people have bad days, people have good days. Like it happens. They change, but it unsettled me that I could make the two different stereotypes about the same people (Rihanna).

I liked it (Welcome Hallway) too because it kind of felt like I was like a third person watching a scenario where someone ... 'cause when they were really cold and unwelcoming, it seemed like people were discriminating against them and stereotyping them, and I was like a third person watching their reaction, while not hurting them, if you know what I mean. So I felt sympathy for them, but then I kind of felt like they were being mean to me by having that cold, unwelcoming kind of reaction, and they were kind of really judgemental, and I felt like I could have been like discriminated against as well, but it was really nice when they were welcoming (Nicky).

Rihanna and Nicky appear to understand that one's identity is not fixed and same; rather, one occupies an identity position that can shift and change depending on circumstances and that this shift and change is made by people deemed "good" - "Oxfam people would not be like that" - and people deemed less good, for example Collingwood football fans. This understanding is however, hard won. Cultural difference still tends to be treated in learning and education (and life at large) as a factor external to, but influencing, individuals and social groups. It is a struggle for Rihanna to construct this difference as residing within "the same people" or the same 
social group - as an internal rather than external relation: "It unsettled me that I could make the two different stereotypes about the same people". I propose that this struggle is conducted in, and prompted by, liminal space and the materialities (moving images, bodies, affects of surprise and shock) that subtend it. It is a struggle between self and other, or categories of same and different.

Welcome Hallway is a complex liminal space "where visitors are made strange unto themselves, discover unsuspected links to each other and are made aware of their own narratives about themselves and those around them" (Witcomb, 2015, p. 164). Thus, when presented with the "judgemental" and "glaring" version of "Oxfam people" over the course of the video display, and declaring that "Oxfam people would not be like that", Rihanna can be claimed to be essentialising: "smoothing" Oxfam members into a singular identity category and not taking differences among them into account. Yet, after some consideration and in connection with the moving images of welcomes withdrawn and extended that play out over the course of the video, this stereotypical response is curbed or checked: "I just made a stereotypical judgement. I just said Oxfam people". In the liminal space of Welcome Hallway where subject positions shift for both viewers and viewed, Rihanna is made strange unto herself. A self assembles that makes stereotypical judgements and that keeps these judgements in check. Like the welcome extended and withdrawn, this self is a liminal entity. Again, "what is between (seemingly fixed and separate acts or events) is where the real action is" (Cooper and Law, 1995, p. 245, original emphasis).

Liminality emerges here as a relational, intensive property of the assemblage of the video installation including its life-sized human participants and cultural content, Rihanna, other school visitors and the mutually implicated practice of viewing and being viewed. Composed of diverse elements, Welcome Hallway brings a liminal space into being through which one can think in a culturally complex and differentiated way. As the exhibition's curator comments, "You might be a Muslim woman who's rejected by the other hijabwearing Muslim women". As the design of the video installation intends to convey, cultural difference lies within, challenging binary and oppositional thinking about categories of race, religion, ethnicity, sexuality and so on. The liminal is "an open form of internal differentiation" and a space of potential critique (Mansaray, 2006, p. 175) such that unhelpful cultural norms can be challenged (e.g. "Muslim women", "Oxfam people", "Collingwood fans").

\section{The salience of liminal spaces of learning}

Liminal spaces have a special salience in the empirical research reported here. Accenting the embodied, the affective and the material, they have the potential to "jump start" the learner out of a comfortable state of mind and into a state of (productive) uncertainty. Thus, in occupying the space of Welcome Hallway, the learner becomes other in relation to others, providing the possibility of "genuine learning" (Semetsky, 2011) and significant social change, change stemming from the insight that individuals and social groups need not be pitted against one another but rather are always already part of each other. In commenting on how, in Deleuzian philosophy, education "becomes a mode of experiential learning from real events in human culture”, Semetsky (2011, p. 140) defines genuine learning as "self-becoming-other in experience". Assembled in relations of identity/difference, whereby one experiences "identical" people extending a heartfelt welcome and withdrawing this welcome, Welcome Hallway provides conditions of possibility for this learning. An ethics and a politics is playing out in the moving images of Welcome Hallway.

Liminal spaces of learning open up in museum learning and education and open up this learning and education, helping on an expanded and more inclusive view of it. Affects, bodies and objects come into the frame. Experiences of learning and liminality are co-produced by and beyond humans (Zembylas, 2016). Thus, the "pod-like" station that is Super Future You can be conceived as a liminal object which opens year 7 students up to experiences beyond the boundaries normally set by human bodies, towards them not only having fun but also affectively attuning to major events like climate change and its potential to transform worlds (human and otherwise). Substantive ontological questions come to the fore, questions that can be sidelined in the field of museum learning and education given that the learning subject is commonly framed as a knowing one. Knowledge, which is taken to be a form of cognitive engagement, has normally been considered the result of attending any museum exhibition. Additionally, museums have long been "thought of solely as authoritative sites for gaining knowledge directly from displayed objects and organised narratives framing an exhibition" (Trofanenko, 2014, p. 25). Framing learning at the museum as a liminal practice enlarges how museum learning is conventionally understood and may provide a useful language for what is already occurring in practice: learning through the in-between by way of interactives and installations such as Super Future You and Welcome Hallway. Spaces that get outside the dualisms that have lasted long in the fields of learning and education (mind-body; cognitiveaffective; thinking-doing; subjects-objects) are on offer and offer a renewed practice of these fields and a reimagined geography of learning and education.

\section{Data availability}

The Data and Methods section provides a full account of data collected. 
Competing interests. The authors declare that they have no conflict of interest.

Edited by: M. Houssay-Holzschuch

Reviewed by: two anonymous referees

\section{References}

Andrews, H. and Roberts, L.: Introduction: Re-mapping liminality, in: Liminal landscapes: Travel, experience and spaces inbetween, edited by: Andrews, H., Taylor and Francis, Hoboken, 2012.

Barad, K.: Meeting the universe halfway: Quantum physics and the entanglement of matter and meaning, Duke University Press, Durham, NC, 2007.

Bauer, I.: Approaching geographies of education differANTly, Children's Geographies, 13, 620-627, 2015.

Bonnell, J. and Simon, R. I.: 'Difficult' exhibitions and intimate encounters, Museum and Society, 5, 65-85, 2007.

Chia, R. and Kallinikos, J.: Epilogue: Interview with Robert Cooper, in: Organized worlds: Explorations in technology and organization with Robert Cooper, edited by: Chia, R., Routledge, London, 1998.

Cooper, R. and Law, J.: Organization: Distal and proximal Views, in: Research in the sociology of organizations: Studies of organizations with European tradition, edited by: Bacharach, S., Gagliardi, P., and Mundell, B., JAI Press, Greenwich, Conn, 1995.

Deleuze, G. and Guattari, F.: Rhizome, in: On the line, Semiotext(e), New York, NY, 1983.

Deleuze, G. and Guattari, F.: A thousand plateaus: Capitalism and schizophrenia, University of Minnesota Press, Minneapolis and London, 1987.

Ellsworth, E.: Places of learning, Routledge, New York, 2005.

Fendler, R.: Becoming-learner: Coordinates for mapping the space and subject of nomadic pedagogy, Qual. Inq., 19, 786-793, 2013.

Fenwick, T. and Landri, P.: Materialities, textures and pedagogies: Socio-material assemblages in education, Pedagogy, Culture \& Society, 20, 1-17, 2012.

Fenwick, T., Edwards, R., and Sawchuk, P.: Emerging approaches to educational research: Tracing the sociomaterial, Routledge, London and New York, 2011.

Hooper-Greenhill, E.: Museums and education: Purpose, pedagogy, performance, Taylor and Francis, Hoboken, 2007.

Horton, J. and Kraftl, P.: What else? Some more ways of doing 'children's geographies', Children's Geographies, 4, 69-95, 2006.

Introna, L.: Epilogue: Performativity and the becoming of sociomaterial assemblages, in: Materiality and space: Organizations, artefacts and practices, edited by: de Vaujany, F.-X. and Mitev, N., Palgrave Macmillan, 2013.

Kennedy, R., Zapasnik, J., McCann, H., and Bruce, M.: All those little machines: Assemblage as transformative theory, Australian Humanities Review, 55, 45-66, 2013.

Kolb, D.: Escaping the museum, Inflexions: A Journal for ResearchCreation, 6, 41-71, 2013.

Kraftl, P.: Geographies of alternative education: Diverse learning spaces for children and young people, Policy Press, Bristol, 2013.
Kraftl, P.: Emotional geographies and the study of education spaces, in: Methodological advances in research on emotion and education, edited by: Zembylas, M. and Schutz, P., Springer International Publishing, Cham, 2016.

Latour, B.: Reassembling the social: An introduction to actornetwork-theory, Oxford University Press, Oxford; New York, 2005.

Law, J.: Actor-network theory and material semiotics, in: The new Blackwell companion to social theory, edited by: Turner, B. S., Wiley-Blackwell, Chichester, UK; Malden, MA, 2009.

Lorimer, J.: More-than-human visual analysis: Witnessing and evoking affect in human-nonhuman interactions, in: Deleuze and research methodologies, edited by: Coleman, R., Edinburgh University Press, Edinburgh, 2013.

Mansaray, A. A.: Liminality and in/exclusion: Exploring the work of teaching assistants, Pedagogy, Culture \& Society, 14, 171187, 2006.

Massey, D.: Space-time, 'science' and the relationship between physical geography and human geography, T. I. Brit. Geogr., 24, 261-276, 1999.

Massumi, B. and McKim, J.: Of microperception and micropolitics: An interview with Brian Massumi, 15 August 2008, Inflexions: A Journal for Research-Creation - Micropolitics: Exploring ethicoaesthetics, 3, 1-20, 2009.

Müller, M.: Assemblages and actor-networks: Rethinking sociomaterial power, politics and space, Geography Compass, 9, 2741, 2015.

Nimmo, R.: Editor's introduction: From generalised symmetry to ontological politics and after - Tracing Actor-Network Theory, in: Actor-network theory research, Volume 1, Emergence, development and transformation - Part One, edited by: Nimmo, R., Sage, 2016.

Parker, J., Crabtree, S. A., bin Baba, I., Carlo, D. P., and Azman, A.: Liminality and learning: International placements as a rite of passage, Asia-Pacific Journal of Social Work and Development, 22, 146-158, 2012.

Puar, J. K.: 'I would rather be a cyborg than a goddess: Becomingintersectional in assemblage theory, philoSOPHIA, 2, 49-66, 2012.

Ringrose, J. and Rawlings, V.: Posthuman performativity, gender and "school bullying": Exploring the material-discursive intraactions of skirts, hair, sluts, and poofs, Confero: Essays on Education, Philosophy and Politics, 3, 80-119, 2015.

Semetsky, I.: Becoming-other: Developing the ethics of integration, Policy Futures in Education, 9, 138-144, 2011.

Sorensen, E.: The materiality of learning, Cambridge University Press, Cambridge, 2009.

Stenner, P. and Moreno-Gabriel, E.: Liminality and affectivity: The case of deceased organ donation, Subjectivity, 6, 229-253, 2013.

Szakolczai, A.: Liminality and Experience: Structuring transitory situations and transformative events, International Political Anthropology, 2, 141-172, 2009.

Tender: Interactive and Multimedia Template, Scienceworks Think Ahead Exhibition, p. 1, 2012.

Thomassen, B.: Liminality and the modern: Living through the inbetween, Ashgate, Farnham, Surrey; Burlington VT, 2014.

Thomassen, B.: Thinking with liminality: To the boundaries of an anthropological concept, in: Breaking boundaries: Varieties of 
liminality, edited by: Horvarth, A., Thomassen, B., and Wydra, H., Berghahn Books, New york; Oxford, 2015.

Trofanenko, B.: Affective emotions: The pedagogical challenges of knowing war, The Review of Education, Pedagogy, and Cultural Studies, 36, 22-39, 2014.

Turner, V.: Betwixt and Between: The Liminal Period in Rites de Passage, in: The Forest of Symbols, Cornell University Press, New York, 1967.

Ward, S.: 'Danger zones': The British 'road movie' and the liminal landscape, in: Liminal landscapes: Travel, experience and spaces in-between, edited by: Andrews, H. and Roberts, L., Taylor and Francis, Hoboken, 2012.

Whatmore, S.: Materialist returns: Practising cultural geography in and for a more-than-human world, Cult. Geogr., 13, 600-609, 2006.

Whitehead, A. N.: Process and reality: An essay in cosmology, Free Press, New York, NY, 1978.

Witcomb, A.: Re-imagining the museum: Beyond the mausoleum, Routledge, London, 2003.
Witcomb, A.: Understanding the role of affect in producing a critical pedagogy for history museums, Museum Management and Curatorship, 28, 255-271, 2013.

Witcomb, A.: Cultural pedagogies in the museum: Walking, listening and feeling, in: Cultural Pedagogies and Human Contact, edited by: Watkins, M., Noble, G., and Driscoll, C., Routledge, London, 2015.

Zembylas, M.: The contribution of non-representational theories in education: Some affective, ethical and political implications, Studies in Philosophy and Education, doi:10.1007/s11217-0169535-2, 2016. 